\title{
DESIGN OF SLAB OF RESIDENTIAL BUILDING FOR WIND LOADING G+10 STOREYS
}

\author{
Rajpal Singh Bumrah \\ M. Tech (Structural Engineering) \\ Vishwavidhyalaya Engineering College (Surguja University), Ambikapur, Surguja, \\ Chhattisgarh, India \\ Aradhna Shrivastava \\ M. Tech (Structural Engineering) \\ Vishwavidhyalaya Engineering College (Surguja University), Ambikapur, Surguja, \\ Chhattisgarh, India \\ Vijay Kumar Shukla \\ , Assistant professor Civil Engineering Department \\ Vishwavidhyalaya Engineering College (Surguja University), Ambikapur, Surguja, \\ Chhattisgarh, India
}

\begin{abstract}
Wind loads are randomly applied dynamic loads. The intensity of the wind pressure on the surface of a structure depends on wind velocity, air density, orientation of the structure, area of contact surface, and shape of the structure. Because of the complexity involved in defining both the dynamic wind load and the behavior of an indeterminate steel structure when subjected to wind loads, the design criteria adopted by building codes and standards have been based on the application of an equivalent static wind pressure. In this project we are going design $G+10$ residential building (with parking) considering wind load in Ambikapur, Surguja by considering Wind load along with dead and live load in designing the high rise building because wind load exerts horizontal load on building. This load on the structure induces large dynamic motions, including oscillations. We have IS CODE-456:2000, IS CODE 875:1987 and Stadd Pro Software for the design.
\end{abstract}

Keywords: - Wind intensity, Wind pressure, High rise structure, Bending moment, Reinforcement, slab design

Cite this Article;.Rajpal Singh Bumrah Aradhna Shrivastava And Vijay Kumar Shukla Design Of Slab Of Residential Building For Wind Loading G+10 Storeys International Journal of Advanced Research in Engineering and Technology, 10(1), 2019,pp,206-215 http://iaeme.com/Home/issue/IJARET?Volume $=10 \&$ Issue $=1$ 


\section{INTRODUCTION}

All building has to bear certain loads which are compulsory to act on structure. We do not give due importance to some of them by just neglecting their effect as they have nearly zero value at certain place while designing any building. But they have their impact on structure on long term basis.

Wind is the motion of air. At earth surface it has very low velocity but as we move higher up the velocity increases as well as wind pressure also. At certain height wind velocity has no or nearly very less effect.

Due to uneven heating of earth hot air rises up as on heating they expand and create a pressure difference due to which air move from high pressure to low pressure area causing wind to blow. Trade wind, polar wind, monsoon wind has its high intensity. Cyclone, tornado is the worst case of moving wind. These high velocity winds create vibration effect on the upper portion of high rise building whereas the lower portion is stationary which has to bear all the loads of structure.

Ambikapur is situated at $23.1355^{\circ} \mathrm{N} \& 83.1818^{\circ} \mathrm{E}$ in surguja district of Chhattisgarh state it is surrounded by mountain terrain from all sides. The Average wind speed is $7.5 \mathrm{mph}$ and Basic wind speed is $35 \mathrm{Km} / \mathrm{h}$ according to meteorological office Ambikapur.

Slab are the most important portion of the building it covers the structure from top portion and act as floor for the subsequent storey's it has to bear the weight of upper floors as well as live and impact load. Flat slab and normal beam column slab are two types of slab mainly designed for structure. Here we will perform the designing of normal beam column slab for the wind load of Ambikapur area.

\section{METHODOLGY AND DESIGN DATA}

The building drawing is constructed in AutoCAD software and the designing is done in STAAD.Pro software. The drawing of building is imported from AutoCAD to STAAD.Pro For analysis and designing in the software for finding out the concrete design.

IS CODES used in the designing are IS 456:2000 for RCC design, IS 875:1957 part I, II, III, V for Dead load, Live load, Wind load and loading combination

\subsection{Drawing detail-}

Built-up area of building is $3700 \mathrm{Sq}$ feet which comprises of 2 Bedroom, Hall and Kitchen. Four unit in each floor. Each unit has one common wash area and dining area separate. Each unit is constructed in $871 \mathrm{Sq}$. feet.

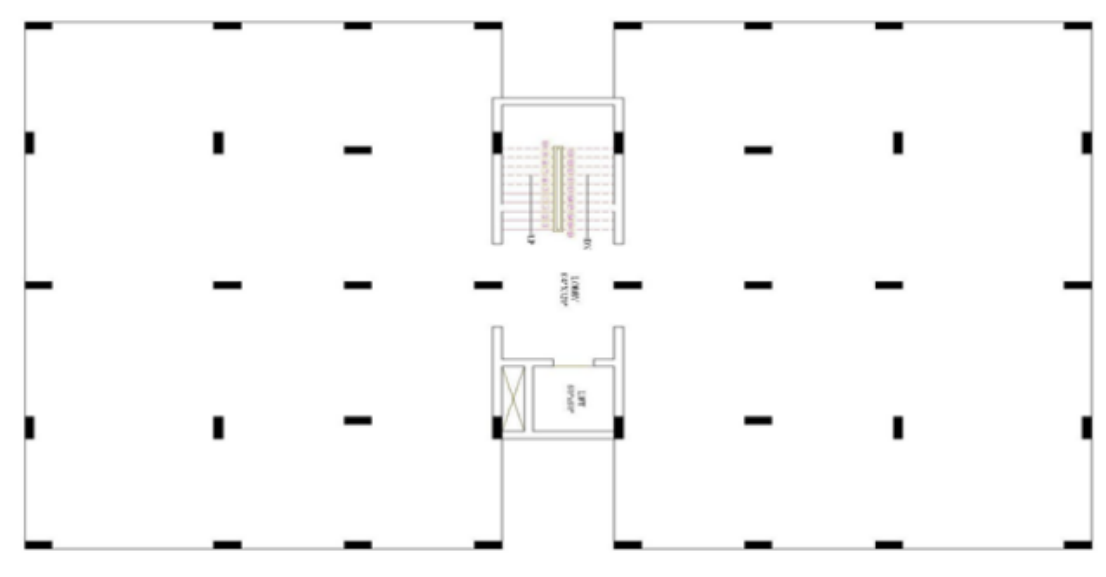

Figure 1 Basement plan of building 


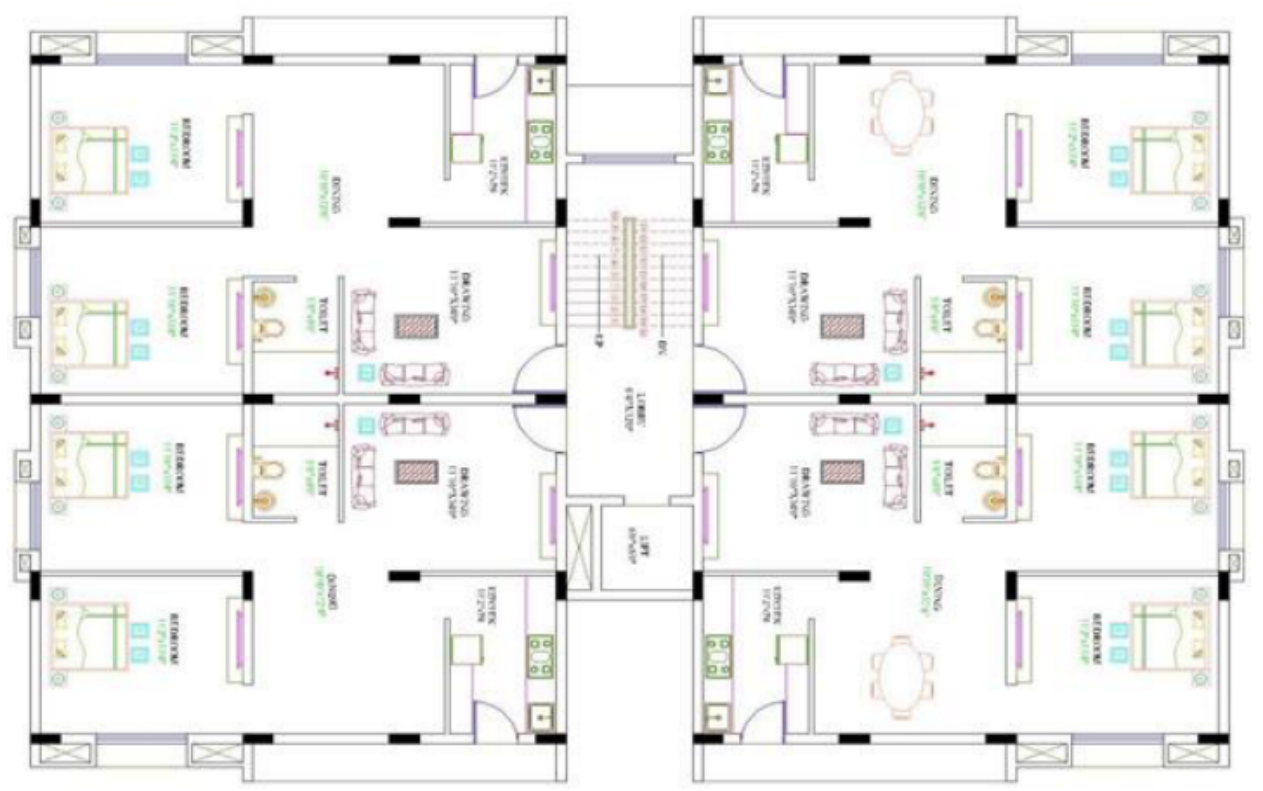

Figure 2 First to Tenth Floor plan

\subsection{Data for Designing of building}

\subsubsection{For Slab design}

Top cover-30 mm, Bottom cover $=30 \mathrm{~mm}$, Thickness of slab-15 cm, Aggregate size $20 \mathrm{~mm}$, Strength of concrete-C25/30, Main reinforcement HYSD 500

\subsubsection{For beam and column}

Column size and beam size-300 mm X 450 mm, 450mm X 300 mm, Column Cover 40 mm, Beam cover $25 \mathrm{~mm}$. Number of stories-11 (G+10),

\subsubsection{Designing Case}

Wind load and combination, Location- Ambikapur Surguja, Chhattisgarh, Type of soilMedium Soil, Type of footing- Raft foundation, Concrete Grade-M25, Steel grade- HYSD 500 bar.

\subsection{Procedure-}

1) Planning of Multistory residential building is carried out in AutoCAD software, and hence decide the place of column and beams.

2) Importing AutoCAD file to Stadd pro software for modeling is carried out by Import command in file menu of Stadd pro.

3) Modeling is carried out using the plan layout which is imported from AutoCAD in 3D Form by grid setting.

4) Applying end condition as fixed one and defining the property of section along with dimensions selection and assigning the properties to member's column, beams and slabs.

5) Defining the loads and load combination as per IS Code 456:2000 and applying them in the structure.

6) Analyzing the structure for Wind loading and then processing the concrete designing to get the concrete design for the building. 


\section{RESULT}

Slab design and Bending moment diagram obtained after designing in Stadd Pro

Table 1: Slab Design detail

\begin{tabular}{|c|c|c|c|c|c|}
\hline \multirow{2}{*}{$\begin{array}{c}\text { Slab } \\
\text { Region no }\end{array}$} & \multirow{2}{*}{$\begin{array}{c}\text { Area } \\
\left.\mathbf{( m m}^{2}\right)\end{array}$} & \multicolumn{2}{|c|}{$\begin{array}{c}\text { Maximum Moment } \\
\text { (kNm) }\end{array}$} & $\begin{array}{c}\text { Reinforcement (Dia. } \\
\text { of bar) }\end{array}$ \\
\cline { 3 - 6 } & & Minor & Major & X axis & Y axis \\
\hline 1 & 9.728 & 1.13 & 3.737 & $12 \mathrm{~mm}$ & $10 \mathrm{~mm}$ \\
\hline 2 & 11.822 & 0.818 & 1.745 & $12 \mathrm{~mm}$ & $10 \mathrm{~mm}$ \\
\hline 3 & 11.822 & 0.829 & 1.889 & $12 \mathrm{~mm}$ & $10 \mathrm{~mm}$ \\
\hline 4 & 9.728 & 1.128 & 3.726 & $12 \mathrm{~mm}$ & $10 \mathrm{~mm}$ \\
\hline 5 & 17.123 & 0.62 & 2.378 & $12 \mathrm{~mm}$ & $10 \mathrm{~mm}$ \\
\hline 6 & 14.09 & 1.649 & 3.37 & $12 \mathrm{~mm}$ & $10 \mathrm{~mm}$ \\
\hline 7 & 10.401 & 0.517 & 3.313 & $12 \mathrm{~mm}$ & $10 \mathrm{~mm}$ \\
\hline 8 & 12.641 & 0.034 & 1.426 & $12 \mathrm{~mm}$ & $10 \mathrm{~mm}$ \\
\hline 9 & 12.641 & 0.032 & 1.437 & $12 \mathrm{~mm}$ & $10 \mathrm{~mm}$ \\
\hline 10 & 10.401 & 0.519 & 3.324 & $12 \mathrm{~mm}$ & $10 \mathrm{~mm}$ \\
\hline 11 & 9.728 & 0.527 & 3.679 & $12 \mathrm{~mm}$ & $10 \mathrm{~mm}$ \\
\hline 12 & 11.822 & 0.29 & 1.458 & $12 \mathrm{~mm}$ & $10 \mathrm{~mm}$ \\
\hline 13 & 11.822 & 0.289 & 1.446 & $12 \mathrm{~mm}$ & $10 \mathrm{~mm}$ \\
\hline 14 & 9.728 & 0.525 & 3.668 & $12 \mathrm{~mm}$ & $10 \mathrm{~mm}$ \\
\hline 15 & 9.728 & 1.128 & 3.726 & $12 \mathrm{~mm}$ & $10 \mathrm{~mm}$ \\
\hline 16 & 11.822 & 0.829 & 1.889 & $12 \mathrm{~mm}$ & $10 \mathrm{~mm}$ \\
\hline 17 & 11.822 & 0.818 & 1.893 & $12 \mathrm{~mm}$ & $10 \mathrm{~mm}$ \\
\hline 18 & 9.728 & 1.13 & 3.737 & $12 \mathrm{~mm}$ & $10 \mathrm{~mm}$ \\
\hline 19 & 9.728 & 0.527 & 3.679 & $12 \mathrm{~mm}$ & $10 \mathrm{~mm}$ \\
\hline 20 & 11.822 & 0.29 & 1.458 & $12 \mathrm{~mm}$ & $10 \mathrm{~mm}$ \\
\hline 21 & 11.822 & 0.289 & 1.446 & $12 \mathrm{~mm}$ & $10 \mathrm{~mm}$ \\
\hline 22 & 9.728 & 0.525 & 3.668 & $12 \mathrm{~mm}$ & $10 \mathrm{~mm}$ \\
\hline 23 & 14.09 & 1.649 & 3.37 & $12 \mathrm{~mm}$ & $10 \mathrm{~mm}$ \\
\hline 24 & 17.123 & 0.62 & 2.377 & $12 \mathrm{~mm}$ & $10 \mathrm{~mm}$ \\
\hline 25 & 17.123 & 0.612 & 2.377 & $12 \mathrm{~mm}$ & $10 \mathrm{~mm}$ \\
\hline 26 & 14.09 & 1.651 & 3.382 & $12 \mathrm{~mm}$ & $10 \mathrm{~mm}$ \\
\hline
\end{tabular}

Bending moment diagrams for hogging and sagging moment in slabs are shown below: - 
Rajpal Singh Bumrah Aradhna Shrivastava and Vijay Kumar Shukla

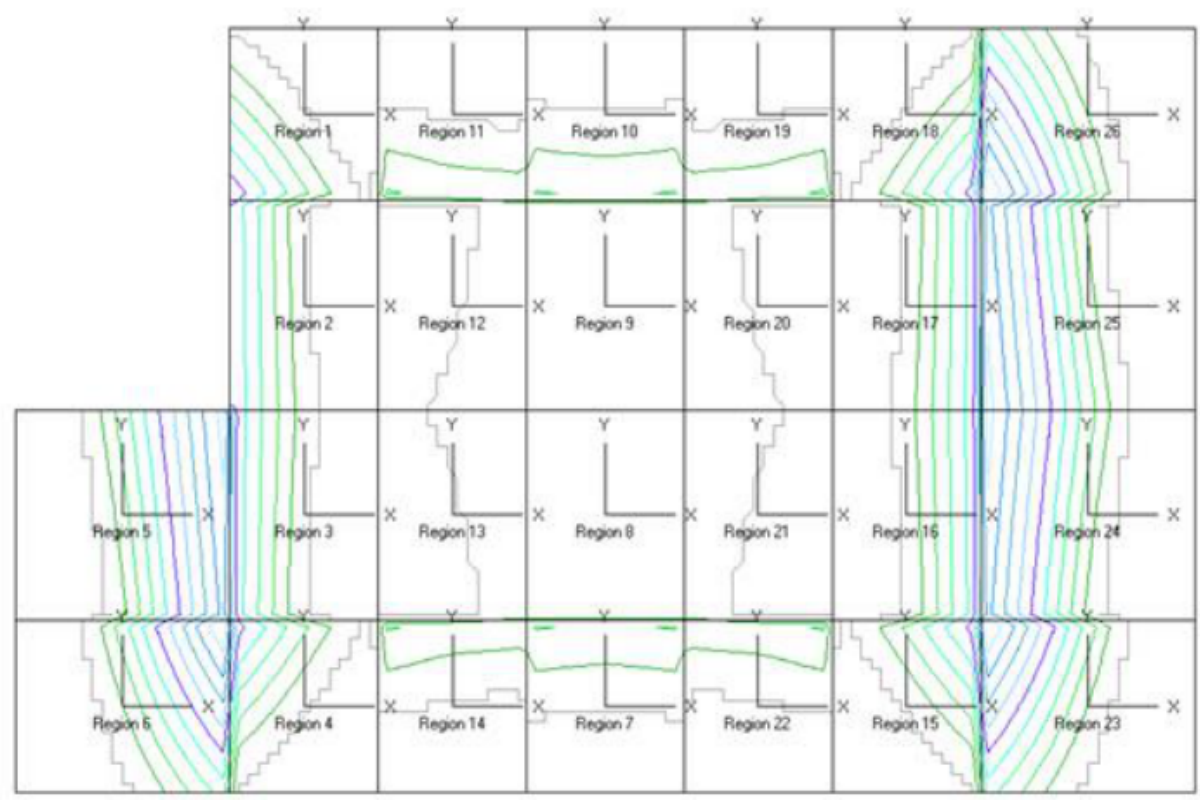

Figure 3 Sagging bending moment in Slab along $\mathrm{X}$ axis

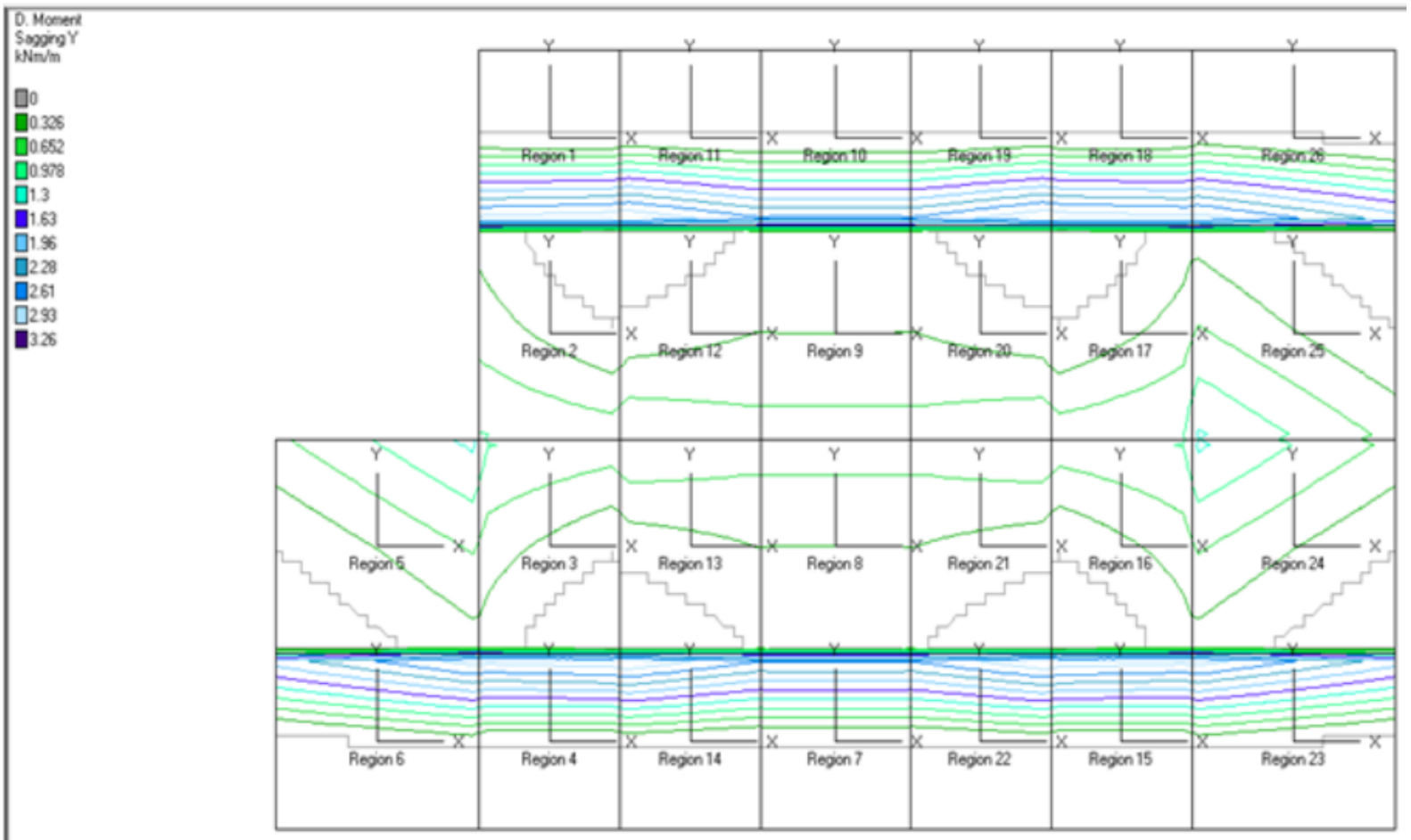

Figure 4 Sagging bending moment in Slab along Y axis 


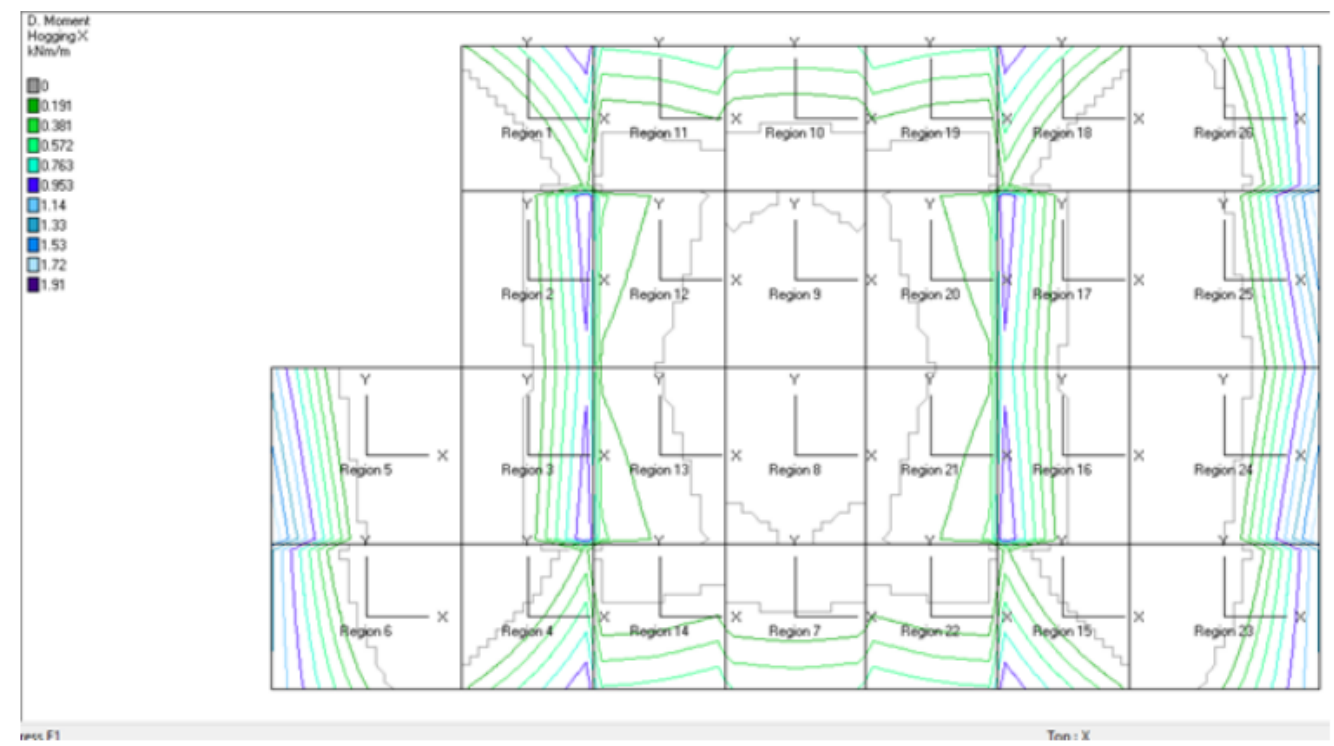

Figure 5 Hogging bending moment in Slab along $\mathrm{X}$ axis

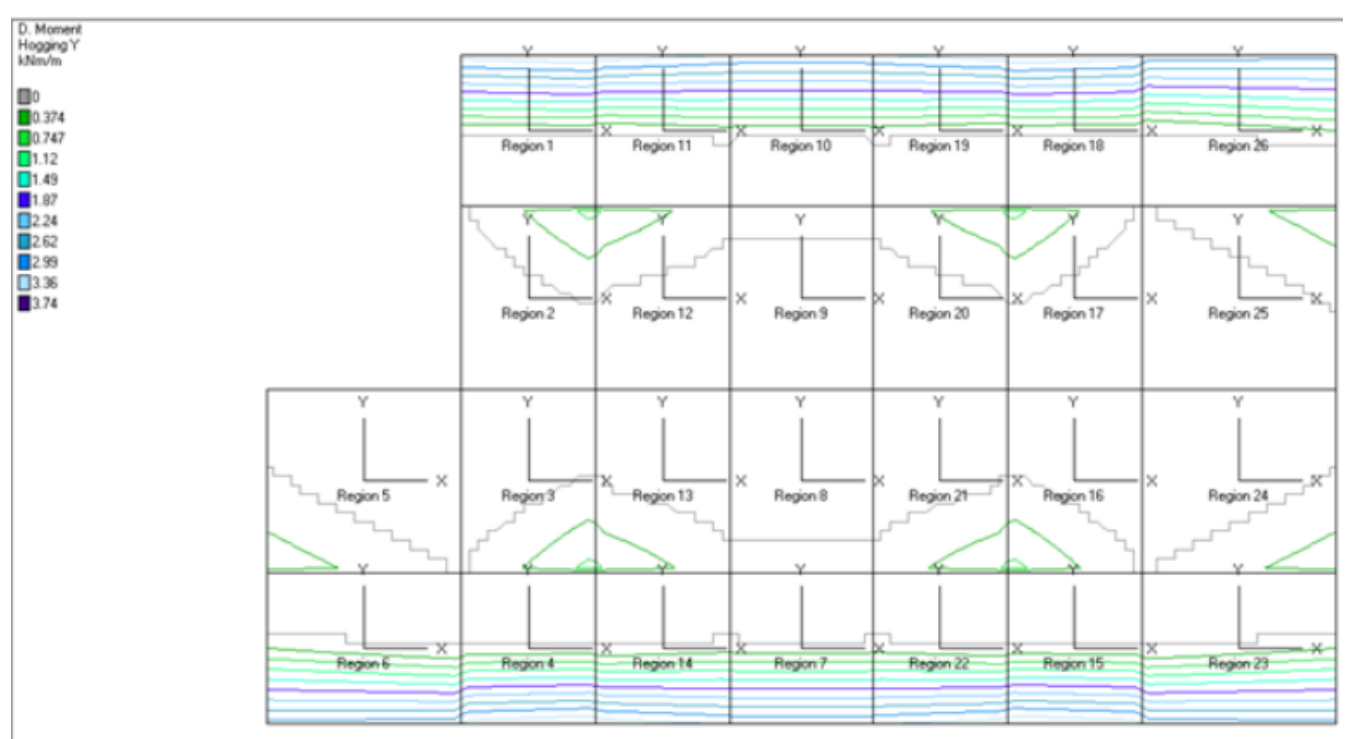

Figure 6 Hogging bending moment in Slab along Y axis

\subsection{Beam and Column Design}

\section{Column Detail}

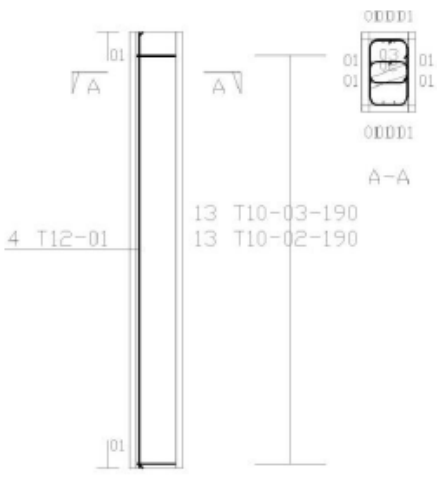


Beam Detail: - 2-12 $\mathrm{mm}$ Bar at top and 2-12 $\mathrm{mm}$ bar at bottom will be required along with curtailment as per design result.
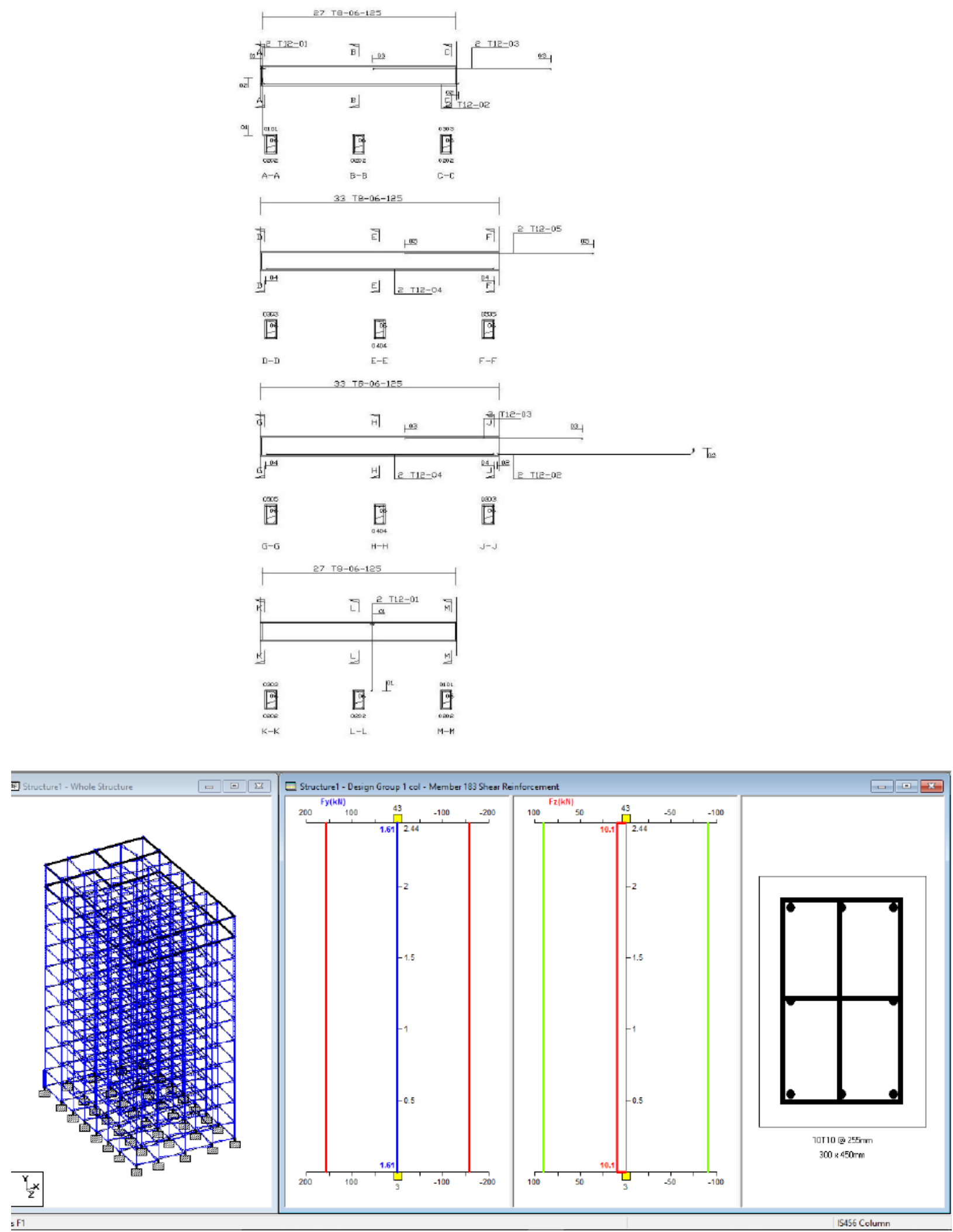

Figure 7 Shear force diagram and column detail for structure 
Table 2 Reinforcement detail for column

\begin{tabular}{|c|c|c|c|}
\hline Position & $\begin{array}{c}\text { Distance to } \\
\text { C/L (cm) }\end{array}$ & Size & No \\
\hline Corner & 9.2 & 16 & 4 \\
\hline Top & 0 & 16 & 2 \\
\hline Side & 0 & 16 & 2 \\
\hline
\end{tabular}

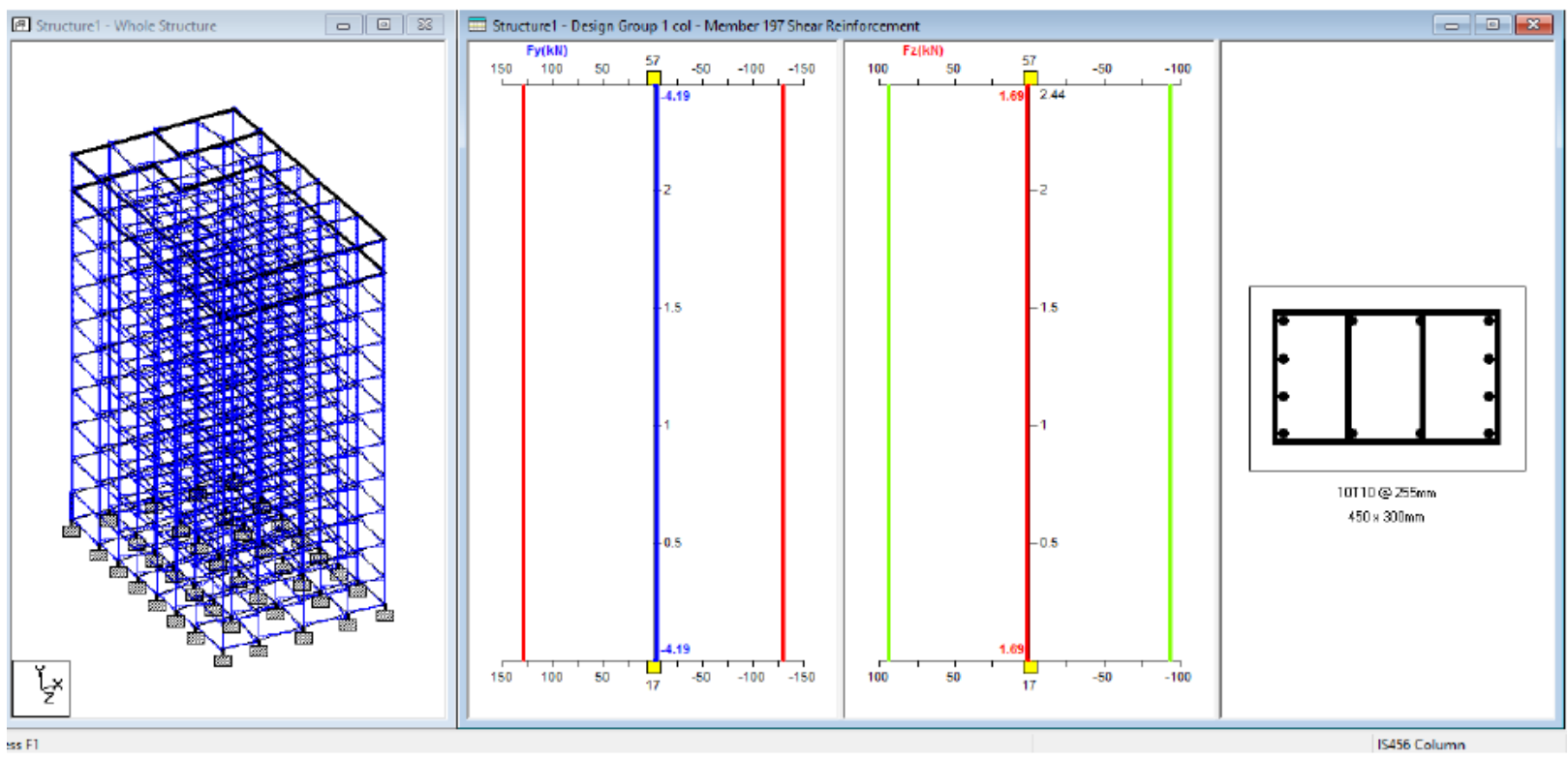

Figure 8 Shear force diagram and column detail for structure

Table 3 Reinforcement detail for column

\begin{tabular}{|l|l|l|l|}
\hline Position & $\begin{array}{c}\text { Distance to } \\
\text { C/L (cm) }\end{array}$ & Size & No \\
\hline Corner & 16.7 & 16 & 4 \\
\hline Top & 08.3 & 16 & 4 \\
\hline Top & 00 & 16 & 2 \\
\hline Side & 4.6 & 16 & 4 \\
\hline Side & 0 & 16 & 2 \\
\hline
\end{tabular}

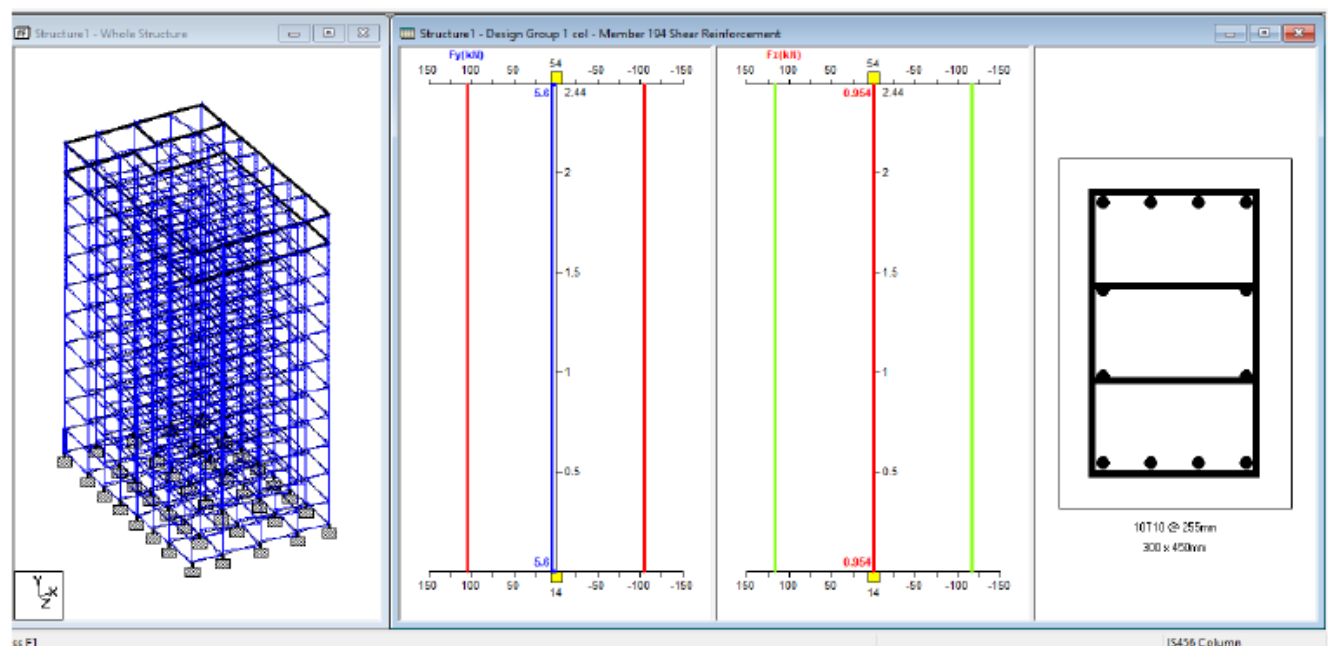

Figure 9 Shear force diagram and column detail for structure 
Table 4 Reinforcement detail for column

\begin{tabular}{|c|c|c|c|}
\hline Position & $\begin{array}{l}\text { Distance to } \\
\text { C/L }(\mathrm{cm})\end{array}$ & Size \\
\hline Corner & 9.4 & $16 / 12$ & 4 \\
\hline Top & 3.1 & $16 / 12$ & 4 \\
\hline Side & 5.6 & $16 / 12$ & 2 \\
\hline
\end{tabular}
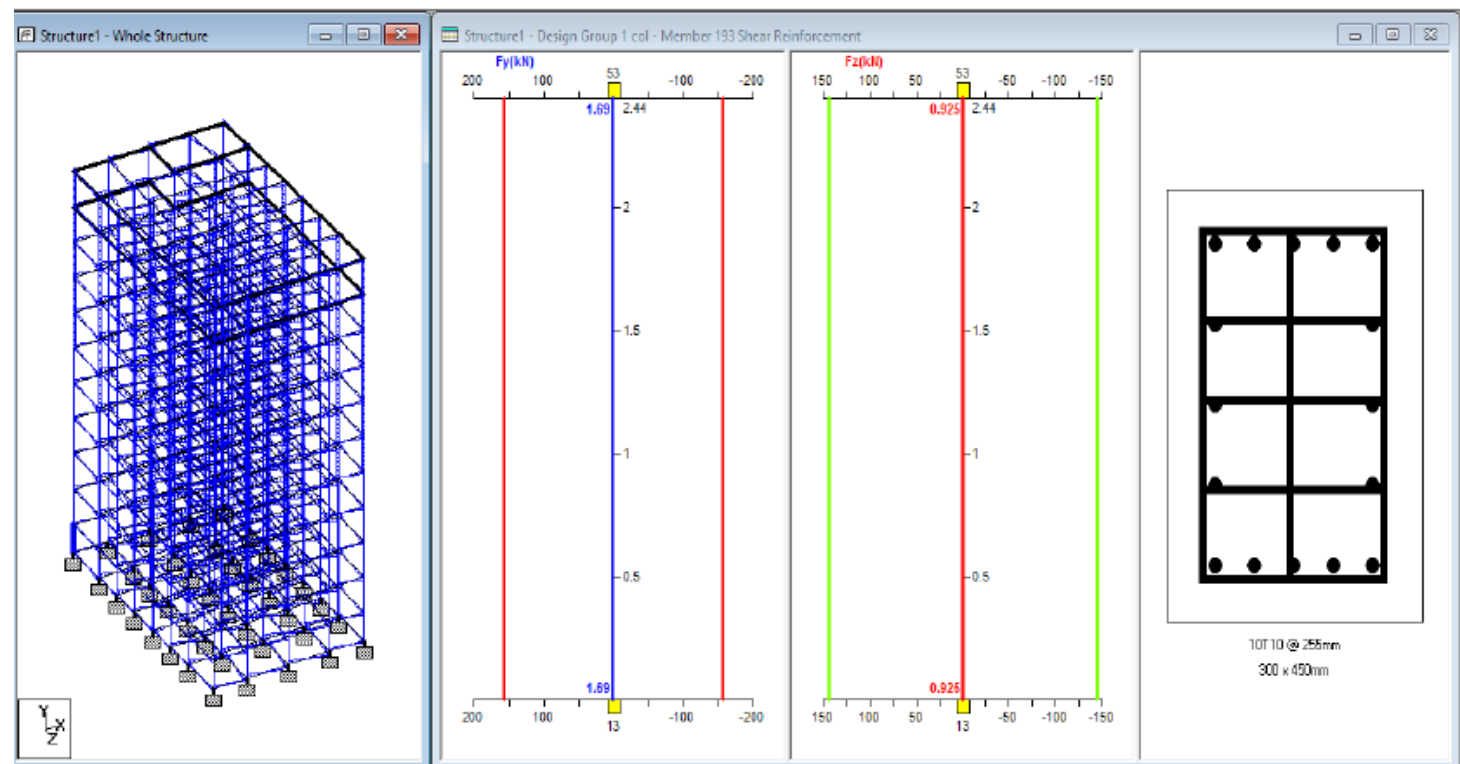

Figure 10 Shear force diagram and column detail for structure

Table 5 Reinforcement detail for column

\begin{tabular}{|c|c|c|c|}
\hline Position & $\begin{array}{c}\text { Distance to } \\
\text { C/L (cm) }\end{array}$ & Size & No \\
\hline Corner & 16.7 & 16 & 4 \\
\hline Top & 4.6 & 16 & 4 \\
\hline Top & 0 & 16 & 2 \\
\hline Side & 8.3 & 16 & 4 \\
\hline Side & 0 & 16 & 2 \\
\hline
\end{tabular}

\section{CONCLUSION}

The building is safe in all the aspect after designing. There will not be any effect of wind on the structure for such wind speed which is prevailing in Ambikapur. Slab is two-way slabs with 12 $\mathrm{mm}$ diameter reinforcing bar along $\mathrm{x}$ axis and $10 \mathrm{~mm}$ diameter bar along y axis. In spite of being $10^{\text {th }}$ storey building the building did not fail in $300 \mathrm{~mm}$ X450 mm column and beam dimension. But accordingly, the reinforcement of bar changes. The beam and column longitudinal reinforcement is of $16 \mathrm{~mm}, 12 \mathrm{~mm}$ and $10 \mathrm{~mm}$ with 10- and 8-mm stirrups @ $350 \mathrm{~mm} \mathrm{c} / \mathrm{c}$.

\section{SCOPE FOR FUTURE WORK-}

We can design the same building using different software and check the results variation in all and also tally the same with analytical one. 


\section{REFERENCES}

[1] Trivedi V, Pahwa. S-International Research journal of Engineering and Technology (IRJET) 1420, Feb-2018 Volume 5 Issue 2

[2] Kumar U, Sharma. A kumar, Kumar, A,Dubey A,- International Research journal of Engineering and Technology(IRJET) 5715, June 2017 Volume 4 Issue 6

[3] Gopal. K Naga Sai, Lingeshwaran. N- International Journal of civil engineering and technology (IJCIET) 2089, April 2017 Volume 8, Issue 4

[4] T.V.V.S. Murali Manohar and N. Jitendra Babu, Effect of Shape of Tall Buildings Subjected to Wind Loading. International Journal of Civil Engineering and Technology, 8(1), 2017, pp. 591601.

[5] Seva Dhanavath, Chandrashekar B, Aseem F. Internataional journal of engineering and computing, 15584, 2017, Volume 7 Issue 11

[6] Indian standard code 456:2000, 875:1987 for designing. 